\title{
COMPLIANCE AND EFFECTIVENESS IN CERVICAL HEADGEAR
}

\begin{abstract}
Objectives: The aim of the present study was to evaluate the correlation between headgear wear duration and correction of skeletal and dental Class II malocclusion in preadolescent patients.
\end{abstract}

Materials and Methods: The study material consisted of pre and posttreatment lateral cephalograms, and actual headgear wear hours calculated from data recorded monthly by an electronic timer device, (Compliance Science System (CSS) and Affirm Smart Headgear Modules, Ortho Kinetics, Vista, California, USA) of 30 patients (14 female and 16 male) treated with cervical headgear for 12 months. The mean age was $10.43 \pm 1.07$ years. Initial and progress cephalograms were analyzed according to skeletal and dental landmarks to evaluate treatment effect of the appliance. The actual number of hours of appliance wear was calculated by data from timer modules collected every monthly visit. Statistical analysis was performed by using SPSS 24.0.

Results: While a sagittal growth was still observed in the group using the headgear for less than 12 hours, restriction of sagittal growth of maxilla was achieved in the group using the cervical headgear over 12 hours daily.

Conclusions: The cervical headgear is still used in orthodontics to restrict the forward growth of the maxilla in Class II division 1 patients with a normal or low angle profile. By means of objective data for monthly appliance usage, this study showed that in order to achieve the targeted results the cervical headgear should be used at least 12 hours daily.
ORCID IDs of the authors: G.T.0000-0001-7261-5504 N.D.0000-0003-4103-6045

${ }^{1}$ Department of Orthodontics, Faculty of Dentistry, Istanbul Yeni Yüzyıl University, Istanbul, Turkey

2 Department of Biostatistics, Faculty of Medicine, Istanbul Yeni Yüzyil University, Istanbul, Turkey

Key Words: Orthodontics, extraoral traction appliances, patient compliance

How to Cite: Trakyalı G, Dayığlu N. Compliance and Effectiveness in Cervical Headgear. Cumhuriyet Dent J 2019;22:2:147-155. 


\section{INTRODUCTION}

Treatment of Class II, Division 1 malocclusion in growing patients compromises growth modification by orthopedic appliances such as cervical headgears, although treatment effect is intimately to patient's compliance and motivation. ${ }^{1-3}$ The skeletal and dental effects of cervical headgear in growing patients depends on magnitude of force and time of daily use. ${ }^{4,5}$

Orthodontists currently recommend 'standard' wear times with a broad deviation in practice ranging from 12 to 20 hours daily. ${ }^{6-14}$ However, lack of an objective measure of compliance makes it difficult to describe the dose effect relationship between headgear wear and Class II correction. ${ }^{15}$

In order to more accurately monitor compliance, several studies have tried to measure orthodontic patient compliance using electronic measuring devices. ${ }^{6,716-20}$ The first reported use of a headgear-timing device was by Northcutt. ${ }^{21}$ This timing headgear design was a sophisticated, miniaturized electronic clock that counted the number of hours that a headgear was worn. Mitchell ${ }^{22}$ used the timer headgear on patients with a history of poor compliance and gained sufficient improvement in patient cooperation.

Cureton et $a .^{22}$ developed a timing device based on a small quartz calendar watch concealed in a headgear strap and activated by a small switch attached to a traction module. Later, Güray and Orhan ${ }^{6}$ created their own timing headgear device. Many studies have found that these timing devices are useful in measuring patient compliance during orthodontic treatment with removable appliances. ${ }^{7,18,19}$ Cole $^{19}$ used a commercially available timing headgear [Compliance Science System (CSS), Ortho Kinetics Corporation, Vista, California, USA] on 20 patients to encourage motivation. Doruk et $a l^{7}$ also used the CSS to evaluate the efficacy of timer modules on patient cooperation.

The aim of the present study is to evaluate the most favorable headgear wear duration for cervical headgear treatment of Class II, Division 1 growing patients.

\section{MATERIALS AND METHODS}

Forty eight consecutive patients presenting Class II, Division 1 malocclusion with maxillary protrusion were selected from the patients list. The parents of five patients refused to participate. Three patients aged over 12 were eliminated from the study. The mean age of forty subjects ( 21 female and 19 male) included in the study was $10.43 \pm 1.07$.

The headgear used for treatment was the Kloehn type with a long outer bow fitted to the maxillary first molars. Initial force was applied to the long outer bow parallel to the occlusal plane. The outer bow was bent upward at a $20^{\circ}$ angle to the inner bow to tip the maxillary molar roots distally as the crown moved distally. Extraoral traction forces of $600 \mathrm{~g}$ per side were used, and patients were instructed to wear their headgear for 12 to 16 hours a day. Each subject received the same commercially available timing headgear (SCC); which consisted of a microprocessor-controlled timing module embedded in one of the cervical headgear traction modules. The patients used the cervical headgear for an average period of 12 months. All patients were treated by the same orthodontist.

The patients were not informed that their monthly headgear wear time was being recorded. The timer device begins a timing cycle when the module is placed under tension and stops timing when tension is released. At each monthly visit, the module was placed in an infrared reader and the data on the module was transferred to a computer using Affirm Software V 4.2 (Ortho Kinetics Corporation, Vista, California, USA). Due to limited battery life of the timer modules, a second timer module was placed for each patient after 6 months of treatment. Patients who used their headgear for less than 12 hours were assigned to Group 1 and patients who used their headgear for more than 12 hours were assigned to Group 2. Two patients were excluded from the study due to appliance breakage.

To analyze the effects of the cervical headgear therapy, lateral cephalograms were taken before (T1) and after (T2) the treatment using a cephalostat (Cranex DC2, Tuusula, Finland). Lateral cephalograms of the subjects obtained at $\mathrm{T} 1$ and $\mathrm{T} 2$ were scanned, digitized and then analyzed with the Dolphin Imaging Software 9.0 (Los Angeles, 
California, USA) by the same investigator (GT). The

landmarks used in our study are defined in Table 1.

Table 1. The cephalometric variables and explanations used in the study.

\begin{tabular}{|c|c|}
\hline SNA $\left(^{\circ}\right)$ & Angle determined by points $\mathrm{S}, \mathrm{N}$, and $\mathrm{A}$ \\
\hline $\mathrm{SNB}\left({ }^{\circ}\right)$ & Angle determined by points $\mathrm{S}, \mathrm{N}$, and $\mathrm{B}$ \\
\hline $\operatorname{ANB}\left({ }^{\circ}\right)$ & Angle determined by points $\mathrm{A}, \mathrm{N}$, and $\mathrm{B}$ \\
\hline Maxillary depth $\left(^{\circ}\right)$ & Angle formed between FH and NA planes \\
\hline $\operatorname{GoMeSN}\left({ }^{\circ}\right)$ & Angle formed between Go-Me and SN planes \\
\hline Saddle $\left(^{\circ}\right)$ & Angle determined by points $\mathrm{N}, \mathrm{S}$, and $\mathrm{Ar}$ \\
\hline $\operatorname{Ar}\left({ }^{\circ}\right)$ & Angle determined by points $\mathrm{S}, \mathrm{Ar}$, and Go \\
\hline Go $\left({ }^{\circ}\right)$ & Angle determined by points $\mathrm{Ar}$, Go, and Me \\
\hline Maxillary height $\left({ }^{\circ}\right)$ & Angle determined by points $\mathrm{N}, \mathrm{CF}$, and $\mathrm{A}$ \\
\hline FMA $\left(^{\circ}\right)$ & Angle formed between FH plane and the mandibular plane \\
\hline$y$-axis $\left(^{\circ}\right)$ & Angle formed between $\mathrm{FH}$ plane and $\mathrm{S}-\mathrm{Gn}$ \\
\hline SNOcc $\left({ }^{\circ}\right)$ & Angle formed between SN and occlusal planes \\
\hline $\mathrm{SN}(\mathrm{mm})$ & Distance between points $\mathrm{S}$ and $\mathrm{N}$ \\
\hline $\mathrm{SAr}(\mathrm{mm})$ & Distance between points $\mathrm{S}$ and $\mathrm{Ar}$ \\
\hline NperA (mm) & Perpendicular distance from point A to perpendicular line to $\mathrm{FH}$ plane from point $\mathrm{N}$ \\
\hline $\operatorname{PogNB}(\mathrm{mm})$ & Perpendicular distance from pogonion to the plane between points $\mathrm{N}$ and $\mathrm{B}$ \\
\hline Ar-Go (mm) & Distance between points Ar and Go \\
\hline $\mathrm{N}-\mathrm{Me}(\mathrm{mm})$ & Distance between points $\mathrm{N}$ and $\mathrm{Me}$ \\
\hline Ans-Me (mm) & Distance between points Ans and Me \\
\hline Jarabak (ratio) & The ratio between posterior and anterior face heights $(\mathrm{S}-\mathrm{Go} / \mathrm{N}-\mathrm{Me})$ \\
\hline AnsMe/NMe (ratio) & Ratio of lower (Ans-Me) to total $(\mathrm{N}-\mathrm{Me})$ face height \\
\hline SAr/ArGo (ratio) & The ratio between posterior cranial base ( $\mathrm{S}-\mathrm{Ar})$ and ramus $(\mathrm{Ar}-\mathrm{Go})$ \\
\hline Go (ratio) & The ratio between the upper and lower parts of the gonial angle bisected by a line from point $\mathrm{N}$ \\
\hline $\mathrm{U} 1-\mathrm{SN}\left({ }^{\circ}\right)$ & Angle formed between the axis of the maxillary incisor to $\mathrm{SN}$ plane \\
\hline $\operatorname{IMPA}\left({ }^{\circ}\right)$ & Angle formed by the intersection of the mandibular incisor axis to the mandibular plane \\
\hline $\mathrm{U} 1-\mathrm{NA}\left({ }^{\circ}\right)$ & Angle formed by the intersection of the maxillary incisor axis to the plane between points $\mathrm{N}$ and $\mathrm{A}$ \\
\hline $\mathrm{L} 1-\mathrm{NB}\left({ }^{\circ}\right)$ & Angle formed by the intersection of the mandibular incisor axis to the plane between points $\mathrm{N}$ and $\mathrm{B}$ \\
\hline Interincisal $\left(^{\circ}\right)$ & Angle formed by the intersection of the mandibular incisor axis to the maxillary incisor axis \\
\hline Overjet (mm) & Horizontal distance between the tips of the maxillary and mandibular central incisors \\
\hline Overbite (mm) & Vertical distance between the tips of the maxillary and mandibular central incisors \\
\hline $\mathrm{U} 1-\mathrm{NA}(\mathrm{mm})$ & Perpendicular distance from the tip of the maxillary incisor to the plane between points $\mathrm{N}$ and $\mathrm{A}$ \\
\hline $\mathrm{L} 1-\mathrm{NB}(\mathrm{mm})$ & Perpendicular distance from the tip of the mandibular incisor to the plane between points $\mathrm{N}$ and $\mathrm{B}$ \\
\hline Nasolabial $\left({ }^{\circ}\right)$ & Angle determined by points columella, SN, and UL \\
\hline $\mathrm{ULE}(\mathrm{mm})$ & Perpendicular distance from the upper lip point to $\mathrm{E}$ line \\
\hline LLE (mm) & Perpendicular distance from the lower lip point to $\mathrm{E}$ line \\
\hline SNA $\left({ }^{\circ}\right)$ & Angle determined by points $\mathrm{S}, \mathrm{N}$, and $\mathrm{A}$ \\
\hline SNB $\left({ }^{\circ}\right)$ & Angle determined by points $\mathrm{S}, \mathrm{N}$, and $\mathrm{B}$ \\
\hline ANB $\left({ }^{\circ}\right)$ & Angle determined by points $\mathrm{A}, \mathrm{N}$, and $\mathrm{B}$ \\
\hline Maxillary depth $\left(^{\circ}\right)$ & Angle formed between FH and NA planes \\
\hline $\operatorname{GoMeSN}\left({ }^{\circ}\right)$ & Angle formed between Go-Me and SN planes \\
\hline Saddle $\left({ }^{\circ}\right)$ & Angle determined by points $\mathrm{N}, \mathrm{S}$, and $\mathrm{Ar}$ \\
\hline $\operatorname{Ar}\left({ }^{\circ}\right)$ & Angle determined by points $\mathrm{S}, \mathrm{Ar}$, and Go \\
\hline Go $\left({ }^{\circ}\right)$ & Angle determined by points $\mathrm{Ar}$, Go, and $\mathrm{Me}$ \\
\hline Maxillary height $\left({ }^{\circ}\right)$ & Angle determined by points $\mathrm{N}, \mathrm{CF}$, and $\mathrm{A}$ \\
\hline FMA $\left(^{\circ}\right)$ & Angle formed between FH plane and the mandibular plane \\
\hline$y$-axis $\left({ }^{\circ}\right)$ & Angle formed between FH plane and S-Gn \\
\hline SNOcc $\left({ }^{\circ}\right)$ & Angle formed between SN and occlusal planes \\
\hline $\mathrm{SN}(\mathrm{mm})$ & Distance between points $\mathrm{S}$ and $\mathrm{N}$ \\
\hline $\mathrm{SAr}(\mathrm{mm})$ & Distance between points $\mathrm{S}$ and $\mathrm{Ar}$ \\
\hline NperA (mm) & Perpendicular distance from point $\mathrm{A}$ to perpendicular line to $\mathrm{FH}$ plane from point $\mathrm{N}$ \\
\hline $\operatorname{PogNB}(\mathrm{mm})$ & Perpendicular distance from pogonion to the plane between points $\mathrm{N}$ and $\mathrm{B}$ \\
\hline Ar-Go (mm) & Distance between points Ar and Go \\
\hline $\mathrm{N}-\mathrm{Me}(\mathrm{mm})$ & Distance between points $\mathrm{N}$ and $\mathrm{Me}$ \\
\hline Ans-Me (mm) & Distance between points Ans and Me \\
\hline Jarabak (ratio) & The ratio between posterior and anterior face heights $(\mathrm{S}-\mathrm{Go} / \mathrm{N}-\mathrm{Me})$ \\
\hline AnsMe/NMe (ratio) & Ratio of lower (Ans-Me) to total (N-Me) face height \\
\hline
\end{tabular}

Superimpositions of the initial and final traces were carried out in order to evaluate how much growth had taken place in the Ba- $\mathrm{N}$ plane, using $\mathrm{N}$ as the fixed point. Both initial and final point A positions were projected over the Frankfort plane as a horizontal reference. For the vertical reference plane, we projected the anterior and posterior nasal spine positions over the vertical pterygoid in both the initial and final measurements. Positive values were applied when the final point A position was in front of the initial point A position, and similarly, when the final nasal spine position was lower than the 
initial one. We also took into account any rotations that might have arisen in the palatal plane. A positive rotation was defined as when the final palatal plane position had changed in a counterclockwise direction with respect to the initial position, and vice versa, a negative value was assigned to a clockwise rotation. ${ }^{23}$

\section{Method Error}

To estimate method error, twenty randomly selected radiographs were retraced, re-digitized, and re measured after a 1 month interval from the first measurement, by the same examiner. The method error (ME) was estimated using Dahlberg's formula ${ }^{23}, \mathrm{ME}=\sqrt{\sum d^{2} / 2 n}$ where $\mathrm{d}$ is the difference between the first and second measurements (millimeters or degrees) and $n$ is the number of duplicated measurements.

\section{Statistical analysis}

The descriptive statistics were calculated as means and standard deviations. Means and standard deviations for all variables at $\mathrm{T} 1$ and $\mathrm{T} 2$ were calculated and intra group correlation was performed by using Wilcoxon test. The changes between pretreatment and posttreatment values (T2-T1) for both groups were calculated and compared using non-parametric Mann Whitney U Test. $\quad \mathrm{p}<0.05$ was considered statistically significant. Statistical analysis was performed with SPSS 24.0 (SPSS Inc, Chicago, USA).

\section{RESULTS}

The forward growth of the maxillary A-point was greatly restricted by the cervical headgear treatment, while the rest of the facial structures grew forward at a normal rate. Mean changes and standard deviations from $\mathrm{T} 1$ (pretreatment) to $\mathrm{T} 2$ (posttreatment) of angular and linear measurements for Group 1 and Group 2 are shown in Table 2 and Table 3 respectively. Correlation of changes between $\mathrm{T} 1$ and $\mathrm{T} 2$ are shown in Table 4.

Table 2. Mean values, standard deviations and comparison of T1 and T2 values for Group 1 (Wilcoxon test).

\begin{tabular}{|c|c|c|c|c|c|c|c|c|}
\hline \multirow{2}{*}{$\mathrm{n}=15$} & \multicolumn{3}{|c|}{$\mathrm{T} 1$} & \multicolumn{3}{|c|}{$\mathrm{T} 2$} & \multirow[b]{2}{*}{$\mathrm{Z}$} & \multirow[b]{2}{*}{$\mathrm{p}$} \\
\hline & Mean & & SD & Mean & & SD & & \\
\hline SNA $\left(^{\circ}\right)$ & 81.36 & \pm & \pm 2.16 & 82.09 & \pm & 2.39 & 2.27 & 0.023 \\
\hline $\mathrm{SNB}\left({ }^{\circ}\right)$ & 75.69 & \pm & \pm 2.25 & 76.2 & \pm & 2.95 & 1.51 & 0.132 \\
\hline $\mathrm{ANB}\left({ }^{\circ}\right)$ & 5.65 & \pm & \pm 1.7 & 5.82 & \pm & 2.06 & 1.85 & 0.065 \\
\hline SN-Palatal Plane $\left(^{\circ}\right)$ & 6.6 & \pm & \pm 2.56 & 7.38 & \pm & 3.16 & 2.16 & 0.031 \\
\hline Occ Plane - SN $\left(^{\circ}\right)$ & 17.4 & \pm & \pm 2.64 & 16.2 & \pm & 2.89 & 2.61 & 0.009 \\
\hline A-Na Perp (mm) & 0.45 & \pm & \pm 3.42 & 0.81 & \pm & 4 & 0.85 & 0.394 \\
\hline Y-Axis & 60.01 & \pm & \pm 2.48 & 60.02 & \pm & 2.75 & 0.31 & 0.755 \\
\hline MP-SN $\left(^{\circ}\right)$ & 34.65 & \pm & \pm 3.64 & 34.25 & \pm & 3.69 & 1.57 & 0.116 \\
\hline Saddle Angle $\left(^{\circ}\right)$ & 124.12 & \pm & \pm 3.29 & 123.84 & \pm & 4.01 & 0.11 & 0.91 \\
\hline Articular Angle $\left({ }^{\circ}\right)$ & 145.97 & \pm & \pm 5.15 & 146.42 & \pm & 4.06 & 0.17 & 0.865 \\
\hline Gonial Angle $\left(^{\circ}\right)$ & 124.58 & \pm & \pm 5.9 & 123.97 & \pm & 5.07 & 0.79 & 0.433 \\
\hline Sum of Angle $\left(^{\circ}\right)$ & 394.55 & \pm & \pm 3.65 & 394.25 & \pm & 3.69 & 0.97 & 0.33 \\
\hline Pog-N Perpendicular (mm) & -8.39 & \pm & \pm 4.06 & -7.79 & \pm & 4.61 & 0.85 & 0.63 \\
\hline ANS-Me (perp-HP) (mm) & 6.77 & \pm & \pm 2.83 & 63.36 & \pm & 3.57 & 1.25 & 0.211 \\
\hline Anterior Face Height (mm) & 116.73 & \pm & \pm 3.65 & 119.41 & \pm & 3.97 & 2.9 & 0.004 \\
\hline ANS-Me/N-Me & 57.27 & \pm & \pm 1.84 & 56.62 & \pm & 1.78 & 2.53 & 0.011 \\
\hline Posterior Cranial Base (mm) & 35.58 & \pm & \pm 3.59 & 36.42 & \pm & 3.2 & 2.27 & 0.023 \\
\hline S-Go (mm) & 77.07 & \pm & \pm 3.26 & 79.56 & \pm & 3.48 & 2.92 & 0.004 \\
\hline Jarabak ratio $(\%)$ & 63.74 & \pm & \pm 2.59 & 64.26 & \pm & 2.93 & 1.85 & 0.065 \\
\hline S-Ar/Ar-Go (\%) & 83.76 & \pm & \pm 11.92 & 83.9 & \pm & 10.29 & 0.4 & 0.691 \\
\hline Gonial Ratio & 71.83 & \pm & \pm 5.8 & 70.8 & \pm & 5.27 & 1.48 & 0.14 \\
\hline Mandibular Length (Go-Gn) (mm) & 70.23 & \pm & \pm 3.65 & 71.3 & \pm & 5.25 & 1.53 & 0.125 \\
\hline Corpus Length (mm) & 67.66 & \pm & \pm 3.08 & 69.58 & \pm & 3.14 & 2.84 & 0.005 \\
\hline $\mathrm{U} 1-\mathrm{SN}\left({ }^{\circ}\right)$ & 109.56 & \pm & \pm 4.65 & 110.63 & \pm & 4.56 & 1.59 & 0.112 \\
\hline $\mathrm{U} 1-\mathrm{NA}\left({ }^{\circ}\right)$ & 28.22 & \pm & \pm 4.83 & 29.17 & \pm & 5.91 & 1.13 & 0.258 \\
\hline U1-NA (mm) & 6.16 & \pm & \pm 2.05 & 6.12 & \pm & 3.04 & 0.28 & 0.777 \\
\hline $\mathrm{U} 1-\mathrm{FH}\left(^{\circ}\right)$ & 118.59 & \pm & \pm 3.86 & 119.54 & \pm & 5.57 & 1.02 & 0.306 \\
\hline $\operatorname{IMPA}\left({ }^{\circ}\right)$ & 99.26 & \pm & \pm 4.95 & 98.29 & \pm & 4.47 & 1.65 & 0.1 \\
\hline L1-NB $\left(^{\circ}\right)$ & 29.59 & \pm & \pm 5.22 & 28.61 & \pm & 4.31 & 1.51 & 0.132 \\
\hline L1-NB (mm) & 6.55 & \pm & 1.82 & 6.4 & \pm & 1.75 & 1.08 & 0.28 \\
\hline Pog-NB (mm) & 1.16 & \pm & 1.2 & 1.14 & \pm & 1.19 & 0.29 & 0.776 \\
\hline Interincisal Angle $\left({ }^{\circ}\right)$ & 116.52 & \pm & 6.7 & 116.58 & \pm & 7.8 & 0.03 & 0.975 \\
\hline Overjet $(\mathrm{mm})$ & 7.66 & \pm & 2.09 & 7.67 & \pm & 1.68 & 0.71 & 0.48 \\
\hline Overbite (mm) & 3.62 & \pm & 1.64 & 4.15 & \pm & 1.06 & 1.85 & 0.064 \\
\hline
\end{tabular}

T1: Pretreatment, T2: Posttreatment, Statistical significance: $\mathrm{p}<0.05$, SD: Standard Deviation, Z: Difference between pretreatment and posttreatment values. 
Trakyalı $G$, et al.

Table 3. Mean values, standard deviations and comparison of $\mathrm{T} 1$ and $\mathrm{T} 2$ values for Group 2 (Wilcoxon test).

\begin{tabular}{|c|c|c|c|c|c|c|c|c|}
\hline \multirow{2}{*}{$\mathrm{n}=15$} & \multicolumn{3}{|c|}{ T1 } & \multicolumn{3}{|c|}{$\mathrm{T} 2$} & \multirow[b]{2}{*}{$\mathrm{z}$} & \multirow[b]{2}{*}{$\mathrm{p}$} \\
\hline & Mean & & SD & Mean & & SD & & \\
\hline SNA $\left({ }^{\circ}\right)$ & 82.29 & \pm & 3.68 & 81.78 & \pm & 2.81 & 0.63 & 0.532 \\
\hline $\mathrm{SNB}\left(^{\circ}\right)$ & 75.73 & \pm & 2.98 & 77.17 & \pm & 1.95 & 2.3 & 0.021 \\
\hline ANB $\left(^{\circ}\right)$ & 6.5 & \pm & 2.15 & 4.95 & \pm & 1.95 & 3.41 & 0.001 \\
\hline SN-Palatal Plane $\left(^{\circ}\right)$ & 8.85 & \pm & 2.86 & 8.74 & \pm & 2.96 & 0.31 & 0.755 \\
\hline Occ Plane - SN $\left(^{\circ}\right)$ & 19.13 & \pm & 3.96 & 17.42 & \pm & 3.41 & 2.64 & 0.008 \\
\hline A-Na Perp (mm) & 0.56 & \pm & 4.04 & -0.67 & \pm & 3.9 & 2.33 & 0.02 \\
\hline Y-Axis & 60.29 & \pm & 3.86 & 60.52 & \pm & 4.02 & 1.39 & 0.164 \\
\hline $\mathrm{MP}-\mathrm{SN}\left({ }^{\circ}\right)$ & 34.19 & \pm & 4.6 & 33.25 & \pm & 4.39 & 1.56 & 0.118 \\
\hline Saddle Angle $\left({ }^{\circ}\right)$ & 123.75 & \pm & 3.56 & 121.3 & \pm & 5.57 & 1.96 & 0.05 \\
\hline Articular Angle $\left(^{\circ}\right)$ & 146.36 & \pm & 5.83 & 146.25 & \pm & 6.35 & 0.09 & 0.925 \\
\hline Gonial Angle $\left({ }^{\circ}\right)$ & 124.09 & \pm & 5.22 & 123.96 & \pm & 5.64 & 0.23 & 0.82 \\
\hline Sum of Angle $\left(^{\circ}\right)$ & 394.19 & \pm & 4.6 & 393.52 & \pm & 4.33 & 1.19 & 0.233 \\
\hline Pog-N Perpendicular (mm) & -8.99 & \pm & 7.3 & -8.83 & \pm & 7.84 & 2.33 & 0.022 \\
\hline ANS-Me (perp-HP) (mm) & 59.77 & \pm & 3.42 & 60.31 & \pm & 2.84 & 1.51 & 0.132 \\
\hline Anterior Face Height (mm) & 114.86 & \pm & 6.82 & 115.57 & \pm & 4.42 & 1.43 & 0.152 \\
\hline ANS-Me/N-Me & 55.95 & \pm & 1.22 & 55.59 & \pm & 1.67 & 0.94 & 0.346 \\
\hline Posterior Cranial Base (mm) & 34.12 & \pm & 2.62 & 35.1 & \pm & 2.88 & 2.36 & 0.018 \\
\hline S-Go (mm) & 75.61 & \pm & 4.78 & 77.67 & \pm & 4.41 & 2.61 & 0.009 \\
\hline Jarabak ratio $(\%)$ & 64.02 & \pm & 3.22 & 65 & \pm & 3.38 & 2.16 & 0.031 \\
\hline S-Ar/Ar-Go (\%) & 80.57 & \pm & 6.54 & 80.56 & \pm & 6.83 & 0.57 & 0.57 \\
\hline Gonial Ratio & 71.78 & \pm & 6.63 & 71.48 & \pm & 6.24 & 0.65 & 0.514 \\
\hline Mandibular Length (Go-Gn) (mm) & 70 & \pm & 3.97 & 70.37 & \pm & 3.93 & 0.4 & 0.691 \\
\hline Corpus Length (mm) & 66.85 & \pm & 2.82 & 67.8 & \pm & 2.96 & 2.02 & 0.044 \\
\hline U1-SN $\left(^{\circ}\right)$ & 103.28 & \pm & 5.55 & 106.58 & \pm & 7.27 & 2.44 & 0.015 \\
\hline $\mathrm{U} 1-\mathrm{NA}\left({ }^{\circ}\right)$ & 20.91 & \pm & 5.88 & 24.79 & \pm & 7.04 & 2.67 & 0.008 \\
\hline U1-NA (mm) & 3.73 & \pm & 2.47 & 4.95 & \pm & 2.79 & 2.13 & 0.033 \\
\hline U1-FH $\left(^{\circ}\right)$ & 113.4 & \pm & 7.91 & 113.4 & \pm & 7.91 & 1.76 & 0.078 \\
\hline $\operatorname{IMPA}\left({ }^{\circ}\right)$ & 97.93 & \pm & 6.12 & 97.28 & \pm & 8.71 & 0.23 & 0.82 \\
\hline L1-NB $\left(^{\circ}\right)$ & 27.89 & \pm & 5.39 & 28.36 & \pm & 6.26 & 0.57 & 0.572 \\
\hline L1-NB (mm) & 5.76 & \pm & 2.19 & 5.48 & \pm & 2.5 & 1.38 & 0.166 \\
\hline Pog-NB (mm) & 1.78 & \pm & 1,15 & 1.52 & \pm & 1.15 & 2.11 & 0.035 \\
\hline Interincisal Angle $\left(^{\circ}\right)$ & 124.41 & \pm & 10,31 & 121,94 & \pm & 11.73 & 2.33 & 0.02 \\
\hline Overjet $(\mathrm{mm})$ & 7.77 & \pm & 2,59 & 5,82 & \pm & 1.82 & 2.03 & 0.003 \\
\hline Overbite (mm) & 4.1 & \pm & 2,14 & 3,78 & \pm & 1.92 & 1.14 & 0.256 \\
\hline
\end{tabular}

T1: Pretreatment, T2: Posttreatment, Statistical significance: $\mathrm{p}<0.05$ SD: Standard Deviation, Z: Difference between pretreatment and posttreatment values. 
Table 4. Correlation of differences between T2-T1 for Group 1 and Group 2 (Mann Whitney U test).

\begin{tabular}{|c|c|c|c|c|c|c|c|c|}
\hline \multirow{2}{*}{$\mathrm{n}=15$} & \multicolumn{3}{|c|}{ Group 1} & \multicolumn{3}{|c|}{ Group 2} & \multirow[b]{2}{*}{$\mathrm{Z}$} & \multirow[b]{2}{*}{$\mathrm{p}$} \\
\hline & Mean & & SD & Mean & & $\mathrm{SD}$ & & \\
\hline SNA $\left(^{\circ}\right)$ & 0.72 & \pm & 1.17 & -0.51 & \pm & 2.12 & -1.89 & 0.059 \\
\hline $\mathrm{SNB}\left(^{\circ}\right)$ & 0.51 & \pm & 1.2 & 1.44 & \pm & 2.37 & -1.68 & 0.0928 \\
\hline $\mathrm{ANB}\left(^{\circ}\right)$ & 0.16 & \pm & 1.77 & -1.91 & \pm & 1.91 & -3.92 & 0.0005 \\
\hline SN-Palatal Plane $\left(^{\circ}\right)$ & 0.77 & \pm & 1.22 & -0.11 & \pm & 2.35 & -1.35 & 0.1773 \\
\hline Occ Plane - SN $\left(^{\circ}\right)$ & -1.2 & \pm & 1.36 & -1.71 & \pm & 2.02 & -0.68 & 0.4933 \\
\hline A-Na Perp (mm) & 0.35 & \pm & 1.7 & -1.23 & \pm & 2.14 & -2.61 & 0.009 \\
\hline Y-Axis & 0.007 & \pm & 2.12 & 0.23 & \pm & 1.41 & -1.6 & 0.2452 \\
\hline MP-SN $\left(^{\circ}\right)$ & -0.4 & \pm & 1.12 & -0.04 & \pm & 2.34 & -0.79 & 0.4303 \\
\hline Saddle Angle $\left(^{\circ}\right)$ & -0.27 & \pm & 1.85 & -2.45 & \pm & 4.95 & -1.41 & 0.1582 \\
\hline Articular Angle $\left(^{\circ}\right)$ & 0.45 & \pm & 2.94 & -0.11 & \pm & 4.08 & -0.35 & 0.7242 \\
\hline Gonial Angle $\left(^{\circ}\right)$ & -0.6 & \pm & 2.47 & -0.13 & \pm & 2.23 & -0.56 & 0.5753 \\
\hline Sum of Angle $\left(^{\circ}\right)$ & -0.29 & \pm & 1.2 & -0.67 & \pm & 2.22 & -0.52 & 0.604 \\
\hline Pog-N Perpendicular (mm) & 0.6 & \pm & 3.11 & 0.16 & \pm & 2.04 & -0.42 & 0.678 \\
\hline ANS-Me (perp-HP) (mm) & 0.58 & \pm & 1.93 & 0.54 & \pm & 2.27 & -0.31 & 0.756 \\
\hline Anterior Face Height (mm) & 2.68 & \pm & 2.55 & 0.71 & \pm & 4.49 & -1.04 & 0.3 \\
\hline ANS-Me/N-Me & -0.65 & \pm & 0.83 & -0.36 & \pm & 1.59 & -0.21 & 0.8355 \\
\hline Posterior Cranial Base (mm) & 0.83 & \pm & 1.14 & 0.98 & \pm & 1.42 & -0.46 & 0.648 \\
\hline S-Go $(\mathrm{mm})$ & 2.49 & \pm & 2.36 & 2.06 & \pm & 2.46 & -0.39 & 0.693 \\
\hline Jarabak ratio $(\%)$ & 0.52 & \pm & 1.08 & 0.98 & \pm & 1.66 & -1.02 & 0.309 \\
\hline S-Ar/Ar-Go (\%) & 0.14 & \pm & 4.89 & -0.007 & \pm & 4.62 & -0.6 & 0.5475 \\
\hline Gonial Ratio & -1.03 & \pm & 2.29 & -0.3 & \pm & 2.09 & -0.52 & 0.604 \\
\hline Mandibular Length (Go-Gn) (mm) & 1.06 & \pm & 2.84 & 0.37 & \pm & 2.92 & -0.62 & 0.534 \\
\hline Corpus Length (mm) & 1.92 & \pm & 2.05 & 0.95 & \pm & 2.81 & -0.68 & 0.494 \\
\hline U1-SN $\left(^{\circ}\right)$ & 1.06 & \pm & 2.44 & 3.3 & \pm & 4.81 & -2.2 & 0.0279 \\
\hline U1-NA $\left(^{\circ}\right)$ & 0.95 & \pm & 2.86 & 3.88 & \pm & 4.22 & -2.59 & 0.0095 \\
\hline U1-NA (mm) & -0.04 & \pm & 1.44 & 0.86 & \pm & 1.73 & -1.91 & 0.05 \\
\hline U1-FH $\left(^{\circ}\right)$ & 0.94 & \pm & 3.71 & 2.08 & \pm & 4.93 & -0.93 & 0.3503 \\
\hline $\operatorname{IMPA}\left({ }^{\circ}\right)$ & -0.96 & \pm & 2.71 & -0.65 & \pm & 6.08 & -1.22 & 0.221 \\
\hline L1-NB $\left(^{\circ}\right)$ & -0.98 & \pm & 2.74 & 0.46 & \pm & 3.23 & -1.18 & 0.2369 \\
\hline L1-NB (mm) & -0.15 & \pm & 1.13 & -0.28 & \pm & 0.81 & -0.15 & 0.884 \\
\hline Pog-NB (mm) & -0.02 & \pm & 0.4 & -0.26 & \pm & 0.43 & -1.6 & 0.109 \\
\hline Interincisal Angle $\left(^{\circ}\right)$ & -0.06 & \pm & 3.25 & -2.46 & \pm & 6.15 & -2.22 & 0.0265 \\
\hline Overjet (mm) & 0.01 & \pm & 1.91 & -1.95 & \pm & 2.21 & -2.64 & 0.008 \\
\hline Overbite (mm) & 0.53 & \pm & 0.98 & -0.32 & \pm & 1.55 & -2.01 & 0.044 \\
\hline
\end{tabular}

T1: Pretreatment, T2: Posttreatment, Statistical significance: $\mathrm{p}<0.05$, SD: Standard Deviation, Z: Difference between pretreatment and posttreatment values.

In Group 2, the SNA angle decreased an average of $0.51^{\circ}\left( \pm 2.12^{\circ}\right)$, whereas there was an increase in SNA angle of $1.44^{\circ}\left( \pm 2.37^{\circ}\right)$ in Group 1. The difference between the two groups was significant $(p=0.05)$. SNB was not affected by CHG therapy and increased slightly during growth in both groups. The reduction of ANB was more obvious in Group 2 with a difference of $1.91^{\circ}( \pm$ $1.91^{\circ}$ ) among the two groups ( $\left.\mathrm{p}<0.05\right)$.

The perpendicular distance of point $\mathrm{A}$ to the NA Line increased with an average of $0.35 \mathrm{~mm}( \pm$ $1.70 \mathrm{~mm}$ ) and decreased with an average of 1.23 $\mathrm{mm}( \pm 2.14 \mathrm{~mm})$ in Group 1 and 2 respectively. The difference between both groups was statistically significant $(p<0.05)$.

A statistically significant difference was observed for the change of overjet and overbite $(P<0.05)$ when two groups were compared. A decrease of $1.95 \mathrm{~mm}( \pm 2.21 \mathrm{~mm})$ and an increase of $0.01 \mathrm{~mm}( \pm 1.91 \mathrm{~mm})$ in the overjet was observed in Group 2 and 1 respectively. Maxillary incisors were protruded with an increase of $3.30^{\circ}$ $\left( \pm 4.8^{\circ}\right)$ in the U1SN and $3.88^{\circ}\left( \pm 4.22^{\circ}\right)$ in the U1NA angle in Group 2.

A similar downward displacement of all skeletal variables was observed in both groups. Overbite reduction was more pronounced in Group $2(-0.32 \pm 1.55 \mathrm{~mm})$ compared with Group $1(0.53 \pm 0.98 \mathrm{~mm}, p<0.05)$.

\section{DISCUSSION}

The majority of orthodontic patients consist of growing children with Class II malocclusion. Extraoral appliances are frequently used for orthopedic corrections of these patients. Some researchers indicated that the headgear can be considered contraindicated in the treatment of Class II malocclusions since it depends on patient compliance.$^{19}$ Compliance is more easily achieved with part-time wear, primarily while sleeping ${ }^{19}$ Results of the present study indicate that 12 hours usage of CHG daily is sufficient to achieve 
successful results in restriction of maxillary forward displacement and maxillary growth.

The results of this study demonstrated that facial profile improved by decreasing facial convexity and the angle of the mandibular plane to the Frankfort horizontal plane, and simultaneously increasing the facial axis and its angle when CHG is used more than 12 hours per day. As a result of these changes, protrusion of the chin was observed. These results indicate that in our sample the $\mathrm{CHG}$ produced a favorable change in the direction of facial growth from vertical to more horizontal. No significant decrease of the same planes was observed in the group in which the CHG was used less than 12 hours. There was no significant difference between the 2 groups in overall forward movement of the chin from pretreatment to posttreatment. These results are similar to the results of a previous study of compared CHG treatment effects with non-treated patients. ${ }^{24}$

In the present study, there was an important retrusive effect on the maxilla in Group 2. This effect is directly related to the more posterior position of point A after treatment. The forward growth of the maxillary A-point was greatly restricted by the $\mathrm{CHG}$ treatment, while the rest of the facial structures grew forward at a normal rate. The results obtained for sagittal changes are consistent with findings documented in the literature where changes in SNA angles ranging from $-0.9^{\circ}$ to $-2.7^{\circ}$, changes in SNB angles ranging from $0^{\circ}$ to $+1.0^{\circ}$, and changes in ANB angles ranging from $-0.6^{\circ}$ to $3.3^{\circ}$ were presented. ${ }^{25-29}$

Headgear wear has been recommended for 14 hours each day. ${ }^{13,14}$ This amount of wear generally produces satisfactory tooth movement with all types of headgear. ${ }^{30}$ According to Graber and Swain, ${ }^{13}$ the duration of force is the critical factor for clinical success. However, clinicians are unaware of the effect of partial compliance on the rate of Class II correction. ${ }^{31}$ According to Ramsay et al. ${ }^{15}$, the lack of an objective measure of compliance makes it difficult to describe the dose-effect relationship between headgear wear and Class II correction. Hence, when headgear wear effects are evaluated, it is more important to know the frequency and duration of use than the level of force applied. ${ }^{32}$
Because most orthodontists report satisfaction with the tooth-movement results from their headgear patients, ${ }^{14,30}$ it is possible that the orthodontic and orthopedic goals can be met with fewer hours of wear than usually recommended.

In a previous study the subjects were asked to wear the headgear 12 to 14 hours a day, in the evenings and at nights, and to keep a daily diary of their headgear wear. ${ }^{33}$ Cooperation was estimated using the diary notes as well as the signs of use in the device, including the tearing of the elastic band and the neck strap. ${ }^{33}$ These methods were found to be not reliable for estimating exact time of usage. ${ }^{34}$

In the present study timer device attached to the traction module of the $\mathrm{CHG}$ was used in order to record exact time and duration of $\mathrm{CHG}$ usage between every visit. The headgear traction module consists of a NiTi coil spring which applies 600 gram standard force when activated on each side. By this module design reliable data of force and force duration was achieved. By using reliable data of usage with a standard force the relationship between usage time and effectiveness of $\mathrm{CHG}$ could be observed.

To understand the relationship between degree of orthopedic effectiveness and usage time of removable extraoral appliances, future studies with bigger sample sizes should be planned.

\section{CONCLUSIONS}

In the limitations of the present study, it can be concluded that:

Restricting forward growth of the maxilla in growing Class II patients, by using CHG applying a standard force 600 grams on both sides, can only be achieved if the appliance is used at least 12 hours daily during the treatment period.

It is important to use a monitoring system, like a timer device placed on the headgear, to motivate and monitor patients using removable appliances in order to gain favorable results.

The timer module consists of a timer and NiTi springs which are activated when the CHG is activated and a standard force is applied during the whole treatment which can be measured in means of duration and amount in order to achieve predictable results. 


\section{ACKNOWLEDGEMENTS}

None

\section{CONFLICTS OF INTEREST}

None

\section{Servikal Headgear Kullanımında Kooperasyon ve Etkinlik \\ $\ddot{O} Z$}

Amaç: Bu çalışmanin amacı, genç bireylerde, servikal headgear kullanım süresi ile iskeletsel ve dental Sinıf II malokluzyonun tedavi sonucu arasindaki ilişkinin değerlendirilmesidir. Gereçler ve Yöntemler: Çalışma materyali, servikal headgear ile tedavi olan, ortalama yaş aralı̆̆ 10,43 $\pm 1,07$ olan 30 hastanin (14 klz ve 16 erkek) tedavi öncesi ve tedavi sonrasi lateral sefalometrik radyografileri ve dijital bir modül, (Compliance Science System (CSS) and Affirm Smart Headgear Modules, Ortho Kinetics, Vista, California, USA) ile kaydedilen aylık aparey kullanım sürelerini gösteren verilerden oluşmuştur. Apareyin tedavi üzerindeki etkinliği hastaların tedavi öncesi ve sonrası lateral sefalamoterik radyografilerinin üzerinde belirlenen iskeletsel ve dental noktalar kullanilarak yapılan ölçümler ile belirlenmiş̧tir. Aparey kullanım süreleri her ay kontrol randevularinda modüllerin okutulması ile elde edilmiştir. İstatistiksel analizler SPSS 24.0 programı kullanılarak yapılmıştır. Bulgular: Apareyi 12 saatten fazla kullanan grupta maksillanin sagittal yön büyümesinin frenlendiği gözlenirken, apareyi 12 saatten daha az kullanan hastalarda sagittal yönde maksiller büyümenin olduğu gözlenmiştir. Sonuçlar: Servikal headgear, Sinif II bölüm 1 malokluzyon tedavisinde maksiller büyümeyi frenlemek amacı ile kullanılan bir apareydir. Bu çalışmada, servikal headgear kullanımında istenilen hedefe erişilmesi için apareyin günde en az 12 saat kullanılması gerektiği objektif veriler kullanılarak ortaya konulmuştur.

Anahtar Kelimeler: Ortodonti, ağız dışı çekme aletleri, hasta иуити.

\section{REFERENCES}

1. Kirjavainen $M$, Kirjavainen $T$, Haavikko $K$. Changes in dental arch dimensions by use of an orthopedic cervical headgear in Class II correction. Am J Orthod Dentofacial Orthop 1997;111:59-66.

2. Kirjavainen $M$, Kirjavainen $T$, Hurmerinta $K$, Haavikko K. Orthopedic cervical headgear with an expanded inner bow in Class II correction. Angle Orthod 2000;70:317-325.

3. Kirjavainen M, Kirjavainen T. Maxillary expansion in Class II correction with orthopedic cervical headgear: a posteroanterior cephalometric study. Angle Orthod 2003;73:281-285.

4. Wieslander L. Early or late cervical traction therapy of Class II malocclusion in the mixed dentition. Am J Orthod 1975;67:432-439.

5. Allan T, Hodgson E. The use of personality measurements as a determinant of patient cooperation in an orthodontic practice. Am J Orthod 1968;54:433440.

6. Güray E, Orhan M. Selçuk type headgear-timer (STHT). Am J Orthod and Dentofacial Orthop 1997;111:87-92.

7. Doruk C, Ağar U, Babacan H. The role of the headgear timer in extra oral cooperation. Eur J Orthod 2004;26:289-291.

8. Brandão $M$, Pinho HS, Urias D. Clinical and quantitative assessment of headgear compliance: a pilot study. Am J Orthod Dentofacial Orthop 2006;129:239-244.

9. Tortop T, Yüksel S. Treatment and Posttreatment Changes with Combined Headgear Therapy. Angle Orthod 2007;77:857-863.

10. Mossaz CF, Byloff FK, Kiliaridis S. Cervical headgear vs pendulum appliance for the treatment of moderate skeletal Class II malocclusion. Am J Orthod Dentofacial Orthop 2007;132:616-623.

11. Zhang JM, Chen HY, Zhang L. Pancherz's analysis in evaluating the treatment effects of headgearactivator on skeletal Class II divison 1 malocclusion. Hua Xi Kou Qiang Yi Xue Za Zhi 2007;25:557-560.

12. Godt A, Berneburg M, Kalwitzki M, Göz G. Cephalometric analysis of molar and anterior tooth movement during cervical headgear treatment in relation to growth patterns. J Orofac Orthop 2008;69:189-200.

13. Graber TM, Swain BF. Current orthodontic concepts and techniques, 2nd ed; St. Louis: CV Mosby, 1975;365-452.

14. Brandt S, Root TL. Interview: Dr. Terrel L. Root on headgear. J Clin Orthod 1975;9:20-41.

15. Ramsay DS, Soma M, Sarason IG. Enhancing patient adherence: the role of technology and its application to orthodontics. In: McNamara JA Jr, Trotman CA, Ferrara A, editors. Creating the compliance patient. Monograph 33. Craniofacial Growth Series. Ann Arbor: 
Center for Human Growth and Development; University of Michigan; 1996:141-165.

16. Northcutt ME. Updating the timing headgear. Journal of Clinical Orthodontics 1975;9:713-717.

17. Mitchell JI. It's time for the timing headgear. Journal of Clinical Orthodontics 1976;10:919-929.

18. Cureton SL, Regennitter FJ, Yancey JM. The role of the headgear calendar in headgear compliance. Am J Orthod Dentofacial Orthop 1993;104:387-394.

19. Cole W. Accuracy of patient reporting as an indication of headgear compliance. Am J Orthod Dentofacial Orthop 2002;121:419-423.

20. Bos A, Hoogstraten J, Prahl-Andersen B. On the use of personality characteristics in predicting compliance in orthodontic practice. Am J Orthod Dentofacial Orthop 2003;123:568-571.

21. Northcutt ME. The timing headgear. J Clinic Orthod 1974;8:321-324.

22. Cureton SL, Regennitter F, Orbell MG. An accurate, inexpensive headgear timer. J Clinic Orthod 1991;25:749754.

23. Kim HY. Statistical notes for clinical researchers: Evaluation of measurement error 2: Dahlberg's error, Bland-Altman method, and Kappa coefficient. Restor Dent Endod 2013;38:182-185.

24. Kim KR, Muhl ZF. Changes in mandibular growth direction during and after cervical headgear treatment. Am J Orthod Dentofacial Orthop 2001;119:522-530.

25. Koch R, Witt E. Die Headgearbehandlung aus fernröntgenologischer Sicht-eine retrospektive Bewertung. Fortschr Kieferorthop 1977;38:197-204.

26. Pirttiniemi P, Kantomaa $T$, Mäntysaari R, Pykäläinen A, Krusinskiene V, Laitala T, Karikko J.
The effects of early headgear treatment on dental arches and craniofacial morphology: an 8 year report of a randomized study. Eur J Orthod 2005;27:429-436.

27. Tulloch JF, Phillips C, Koch G, Proffit WR. The effect of early intervention on skeletal pattern in Class II malocclusion: A randomized clinical trial. Am J Orthod Dentofacial Orthop 1997;111:391-400.

28. Ülgen M. Kephalometrische Untersuchung der Auswirkungen der Distalbißbehandlung mit dem Aktivator und dem Zervikalheadgear auf das Gesichtsskelett und deren Vergleich. Fortschr Kieferorthop 1981;42:337-348.

29. Wiesländer L. The effect of force on craniofacial development. Am J Orthod 1974;65:531-537.

30. Bowden DE. Theoretical considerations of headgear therapy: literature review. $\mathrm{Br} \mathrm{J}$ Orthod 1978;5:145-152.

31. Kopecky GR, Fishman LS. Timing of cervical headgear based on skeletal maturation. Am J Orthod Dentofacial Orthop 1993;104:162-169.

32. Rodrigues $\mathrm{C}$, Mundstock KS, Mundstock CA. Apresentação do sistema CSS como meio de avaliação de uso dos aparelhos de ancoragem extrabucal. Ortodontia Gaúcha 1999;3:109-117.

33. Kirjavainen $M$, Hurmerinta $K$, Kirjavainen $T$. Facial Profile Changes in Early Class II Correction with Cervical Headgear. Angle Orthod 2007;77:960-967.

34. Trakyali G, Sayınsu K, Müezzinoglu AE, Arun T. Conscious hypnosis as a method for patient motivation in cervical headgear wear-a pilot study. Eur J Orthod 2008;30:147-152. 